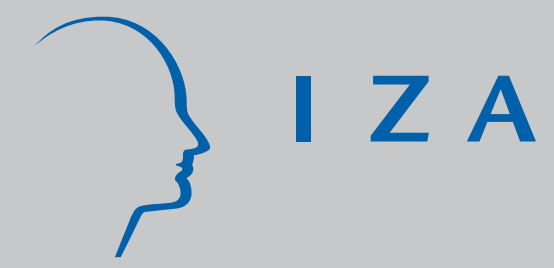

IZA DP No. 1207

The Long and Short of It: Maternity Leave Coverage and Women's Labor Market Outcomes

Masanori Hashimoto

Rick Percy

Teresa Schoellner

Bruce A. Weinberg

J uly 2004 


\title{
The Long and Short of It: Maternity Leave Coverage and Women's Labor Market Outcomes
}

\author{
Masanori Hashimoto \\ Ohio State University and IZA Bonn \\ Rick Percy \\ Capital University \\ Teresa Schoellner \\ Ohio State University
}

Bruce A. Weinberg

Ohio State University and IZA Bonn

Discussion Paper No. 1207

July 2004

IZA

P.O. Box 7240

53072 Bonn

Germany

Phone: +49-228-3894-0

Fax: +49-228-3894-180

Email: iza@iza.org

\begin{abstract}
Any opinions expressed here are those of the author(s) and not those of the institute. Research disseminated by IZA may include views on policy, but the institute itself takes no institutional policy positions.

The Institute for the Study of Labor (IZA) in Bonn is a local and virtual international research center and a place of communication between science, politics and business. IZA is an independent nonprofit company supported by Deutsche Post World Net. The center is associated with the University of Bonn and offers a stimulating research environment through its research networks, research support, and visitors and doctoral programs. IZA engages in (i) original and internationally competitive research in all fields of labor economics, (ii) development of policy concepts, and (iii) dissemination of research results and concepts to the interested public.
\end{abstract}

IZA Discussion Papers often represent preliminary work and are circulated to encourage discussion. Citation of such a paper should account for its provisional character. A revised version may be available on the IZA website (www.iza.org) or directly from the author. 


\section{ABSTRACT \\ The Long and Short of It: Maternity Leave Coverage and Women's Labor Market Outcomes*}

We investigate the effects of maternity leave coverage on women's post-birth wages, job tenure, and labor market attachment. We pay particular attention to unobservable characteristics that are correlated with maternity leave coverage and that affect labor market outcomes. We use a control sample, as well as a range of control variables, to address unobserved heterogeneity. We find evidence of substantial selection based on unobserved heterogeneity. Maternity leave effects on the three outcomes are found to be small and shortlived. This finding is understandable given that most policies in the United States allow leaves for only 12 weeks at most.

JEL Classification: J0, J1, J13, J16, J3, J38, J39

Keywords: female labor market, wages, human capital, public policy, maternity leave

Corresponding author:

Masanori Hashimoto

Department Of Economics

The Ohio State University

410 Arps Hall

1945 North High Street

Columbus, Ohio 43210-1172

USA

Email: Hashimoto.1@osu.edu

\footnotetext{
* Weinberg's research was supported in part by an NSF grant \#0095776 through the Social and Economic Science program. We are grateful for many useful comments offered by the participants at an economics public lecture at Keio University.
} 


\section{Introduction}

Work interruptions are detrimental when enduring employment relationships have a large effect on productivity (Mincer and Polacheck 1974). For example, Blau and Kahn (2000) and Waldfogel (1998a, b) argue that broken ties to employers as a result of child births may account for a large portion of the gender pay gap. ${ }^{1}$

Maternity leave provisions could help alleviate adverse effects when a new child causes the work interruption (Jacobsen and Levin 1995, Klerman and Leibowitz 1997, Waldfogel 1998a, b). ${ }^{2}$ Existing evidence for the United States, Japan, Britain, and other European countries suggests that maternity leave coverage confers wage gains to women (e.g., Klerman and Leibowitz 1997; Ruhm 1998; Barrow 1999; Waldfogel 1998a, b; Waldfogel, Higuchi and Abe 2001).

It is possible that some of the observed positive coverage effects found in individual-level studies are a byproduct of unobserved heterogeneity among women and their employers. Unobserved differences may arise in the worker pool, as women with higher potential earnings sort themselves into jobs with

${ }^{1}$ According to Blau and Kahn, the relative improvement in American women's wages during the 1980 's and 1990's was due mainly to an increase in the labor market attachment of women, accounting for up to 50 percent of the increase in the female-male wage ratio between the 1970s and 1990's. Despite the closing of the gender pay gap, Waldfogel (1998a) finds that the "family gap" among women has increased.

2 Ruhm (1998), Ruhm and Teague (1998), and Waldfogel (1998b) provide highly informative summaries for the US and other countries. A recent finding suggests that maternity leave coverage does not affect men's leave usage (Han and Waldfogel, 2003). 
maternity leave coverage, or amid employers, as jobs requiring more skill tend to offer such benefits. ${ }^{3}$

We address unobserved heterogeneity in a systematic way by using a control sample of women as well as a range of control variables. Since maternity leave likely matters most when a durable employment relationship is valued, it should operate through the preservation of employment relations, either firmspecific human capital or via good matches (Hashimoto 1981, Lazear 1990). Accordingly, we investigate the effects of maternity leave coverage on job tenure and labor market attachment in addition to wages. We study how maternity leave coverage affects the evolution of these outcomes over time by using a control sample to address unobserved heterogeneity. We also explore how the estimates depend on the set of control variables used.

We find that unobserved heterogeneity causes a large bias in estimates of the effect of maternity leave coverage. Once unobserved heterogeneity is controlled for, coverage effects on post-birth wages are short-lived and substantially smaller than previously thought. Maternity leave coverage has significant short-run effects on employment preservation, measured both by job tenure post-birth and the time spent in the labor force; however, it has no longlasting effects. While we are reluctant to speculate about the effect of expanding maternity leave coverage, our finding of small and short-lived maternity leave effects perhaps is understandable given that most maternity leave policies in the

\footnotetext{
${ }^{3}$ Waldfogel reports, however, that estimated maternity leave effects persist after correcting for unobserved heterogeneity by controlling for lagged wages (Waldfogel 1998b).
} 
United States allow leaves for only 12 weeks, with the latter part of that time off being typically without pay.

We also find that controlling for job tenure post-birth and the time spent in the labor force accounts for most of the effects of maternity leave coverage on post-birth wages. This finding suggests that much of the effect of maternity leave on wages operates through the preservation of employment relationships.

Some researchers have argued that maternity leave coverage confers benefits on children as well as on mothers (e.g., Ruhm 2000). The unobserved factors that improve women's labor market outcomes are also likely to benefit their children. Our findings of selection into jobs with maternity leave coverage suggest that it is important to control for individual heterogeneity in estimating the benefits of maternity leave coverage for children from individual level data. This issue is left for a future study.

\section{Data and Sample Construction}

Our sample is taken from the National Longitudinal Survey of Youth of 1979 (NLSY) spanning the years 1979-96. The NLSY is a longitudinal survey of 12,686 people who were between the ages of 14 and 21 as of December 31, 1978. By 1996, the data had been compiled from 17 interviews. Because the majority of the respondents had passed through their primary childbearing years by 1996, this data and its time period are ideal for our purposes.

Of the 12,686 people in the survey, there are 6,283 females. The 4,710 women who reported having a baby at some time during the survey comprise our 
main sample. The 1,573 women who had not borne children as of the last interview date comprise our control sample. ${ }^{4}$ For these latter women, we consider outcomes after a randomly chosen birthday between ages 20 and 29, approximately the distribution of age at childbirth among the women in the sample who bore children. ${ }^{5}$

The details of the sample selection and the means of selected variables are shown in Tables $1 \mathrm{a}$ and $1 \mathrm{~b}$. These female respondents gave birth to 10,498 children in the time span under study, but fourteen observations were lost due to data inconsistencies. ${ }^{6}$ There are 10,378 confinements that constitute the units of observation for this study. ${ }^{7}$ To be able to accurately measure the time path of effects after births, we deleted 293 children who had a non-multiple-birth sibling born within 365 days of their birth. Another 1,242 children were dropped because they were born prior to the first interview in the study.

The variable of primary interest is whether the woman was covered by maternity leave benefits on the job she held before the confinement. This variable is often missing because the question was not asked until 1983 and also was not asked in 1984 . It is missing for 2,077 out of 4,979 , or $42 \%$ of the

\footnotetext{
${ }^{4}$ The control sample includes women who had not born children as of their 1996 interview, at which time they were between ages 31 and 39.

${ }^{5}$ We have experimented with specifications that allow the effect of maternity leave coverage to vary with age. Interactions between coverage and age are not statistically significant, and based on this finding we feel that our results are not sensitive to the use of a randomly selected birthdays.

${ }^{6}$ One case did not list the children's birthdays, while two cases had too few months reported between births. Yet another case with 7 children had birthdays for only the first 6 children. In this last instance, only the last child was eliminated from the study.

${ }^{7}$ That is, there were 10,484 babies born of which 106 were the $2^{\text {nd }}$ listed twin or the $2^{\text {nd }}$ or $3^{\text {rd }}$ listed triplet, leaving a sample of 10,378 confinements.
} 
respondents who were working before the birth and reported a wage. In our samples, 78 percent of the women who bore children and 72 percent of the women who did not bear children had maternity leave coverage.$^{8}$ By the time we completed the cleanup of the data, we were left with 8,843 confinements. The last rows of Tables $1 \mathrm{a}$ and $1 \mathrm{~b}$ indicate that women in our main sample who bore children were slightly less educated, less able (as measured on the Armed Force Qualifying Test), and worked less post-birth than women in the control sample.

One of the primary outcomes we model is the change in the logarithm of post-birth real wages with one of our main independent variables being the prebirth wage. The pre-birth wage was determined by identifying a wage in an interview that was less than 52 weeks prior to the confinement (if the mother was working and reported a wage). Not surprisingly, women who were working before confinement tend to be more educated, more able (as measured by their AFQT scores), and more likely to work after birth than those who were not (cf. rows 3 and 4 in Table 1a).

We investigated the progression of wages annually up to 8 years after the birth. Post-birth wages were computed as a series with the "after" wage for the $\mathrm{i}^{\text {th }}$ year after the birth observed if the woman was working and reported a wage in an interview occurring in the half-closed interval ( $i-1$ years after the birth, $i$ years after the birth]. In the event that two interviews with a valid reported wage

\footnotetext{
${ }^{8}$ Significantly more women with babies are in jobs that have maternity leave coverage, whether they select into those jobs or not. Thus, a 95\% confidence interval for the proportion of women with babies that have maternity leave coverage has a lower limit of $77 \%$; while the upper $95 \%$ confidence limit for women without babies is $74 \%$.
} 
occurred in a single annual period, ${ }^{9}$ the wage rate nearest to the birth was used. Respondents who reported wages below $\$ 1.00$ per hour or over $\$ 100.00$ per hour were eliminated as outliers.

\section{Empirical Strategy}

We study the effect of maternity leave coverage on a range of dependent variables, using variants on a common model. The basic model is:

$$
\ln \left(y_{i c t}\right)=\beta_{t} M A T L E A V E_{i c}+X_{i c} \Gamma_{t}+Z_{i c t} \theta_{t}+\varepsilon_{i c t}
$$

Here $y_{i c t}$ denotes the dependent variable for woman $i$ at the interview in year $t \in\{1, \ldots, 8\}$ after confinement $c$. The dependent variables we consider are wage, job tenure post birth, and the proportion of weeks that the woman worked after child birth. MATLEAVE ${ }_{i c}$ is a dummy variable equal to 1 if woman $i$ was covered by a maternity leave policy at her last interview before confinement $c$; $X_{\text {ic }}$ is the characteristics of woman $i$ at the time of confinement $c$; and $Z_{\text {ict }}$ is the characteristics of woman $i$ in year $t \in\{1, \ldots, 8\}$ after confinement $c$.

From a policy perspective, it is useful to know how expanding the availability of maternity leave coverage affects outcomes. Our specification yields estimates of the effect of the availability of maternity leave coverage. We unfortunately do not have data on whether the maternity leave coverage was used, so we cannot estimate the effect of usage on outcomes.

\footnotetext{
${ }^{9}$ Though the interviews are designed to be annual interviews, they are recorded based on the actual week of the interview; it is possible that the actual duration between interviews could be less than 52 weeks.
} 
We are interested in the immediate effects of maternity leave coverage those that arise in the few years after the birth - as well as the longer-term effects. To this end, we estimate separate models for each of the first eight years after the birth. In order to maximize the sample size, we include all births with valid data, with the result that women with multiple children may contribute multiple observations to each regression.

Women with maternity leave coverage may be inherently different from women without it, but the difference may be unobservable in the data. As mentioned earlier, unobserved differences may arise on the worker side, as women with high earnings sort themselves into jobs with maternity leave coverage, or on the employer side, as jobs requiring more skill tend to offer such benefits. During most of the years under study (1979-96), many U.S. firms were required to offer maternity leave benefits equivalent to their coverage for other medical leaves ${ }^{10}$. Skilled workers are more likely to receive fringe benefits including medical benefits, so women who obtain maternity leave coverage through this route tend to be more skilled than others ${ }^{11}$. Also, employers may commit to hiring women who voluntarily return from maternity leave. If so, we

\footnotetext{
10 At the Federal level, the Pregnancy Discrimination Act (PDA) of 1978 required employers offering leave for temporary disabilities, which effectively includes most medium and large establishments, to treat pregnancy and childbirth in the same way as other temporary disabilities. In addition, several states had supplemented the PDA with stronger temporary disability laws or maternity leave mandates. The Family and Medical Leave Act (FMLA) guaranteeing a jobprotected, unpaid maternity leave of 12 weeks to women working for companies with 50 employees or larger was enacted in 1993. The FMLA also provides for continued health insurance coverage during the leave for those whose employer offers such coverage. See Ruhm (1998) and Waldfogel (1998b) for further details.
}

\footnotetext{
${ }^{11}$ For example, Olson (2000) finds evidence that health insurance coverage increases with the level of education for both men and women.
} 
expect the employers who adopt such policies to be more likely to require specific human capital and good matches. Additionally, we expect them to appeal to women who are inclined to make such specific investments. Therefore, we expect that women with maternity leave coverage will tend to have higher human capital regardless of whether or not they bear children. Unobserved heterogeneity may generate a positive association between maternity leave coverage and labor market outcomes even if the coverage itself has no effects.

We address unobservable heterogeneity by estimating models separately for women who gave birth and for a control sample of women who did not, and by using additional independent variables. To the best of our knowledge, ours is the first study that uses a control sample to address unobserved heterogeneity. Under the assumption, that maternity leave coverage is unlikely to affect wages and other outcomes for women in the control sample, we use these women to gauge the importance of unobserved heterogeneity.

The specifications we employ to further control for unobserved heterogeneity vary by whether we control for (1) pre-birth wage as a proxy for unobserved determinants of productivity or (2) employment history variables such as how long the woman has held the current job and what proportion of the weeks the woman worked in specific periods after childbirth (or a randomly chosen birthday for the control group). By comparing the results from the various specifications, we aim to assess the impact of controls for heterogeneity on the estimated effect of maternity leave coverage on post-birth outcomes. 


\section{Effects on Wages}

Figure 1 plots the maternity leave coefficients for each of the eight years considered using a model that includes whether a woman had maternity leave coverage at her pre-birth job and a set of basic control variables (log of tenure before the birth and its square, the number of weeks elapsed since the last prebirth interview ${ }^{12}$, marital status, education, dummy variables for whether the mother is black and whether she is Hispanic, the mother's score on the Armed Forces Qualifying Test, the mother's age and its square, the birth-order number of the child and its square, and calendar-year dummy variables). ${ }^{13}$ Estimates of the maternity leave coefficients for this and the subsequent figures appear in the Appendix. ${ }^{14}$.

Figure 1 exhibits a large and persistent positive relationship between maternity leave coverage and wages. Thus, in the first three years after the birth, women with maternity leave coverage earn 20 percent more than women without coverage. Although the effects decline as time passes, even in the 7th and 8th years, women with maternity leave coverage earn 10 to 15 percent more than women without it. These estimates are quite large - the equivalent of the returns to a year or two of schooling - and are quite similar to previous estimates found in these data by Waldfogel (1998b) in both magnitude and persistence.

\footnotetext{
${ }^{12}$ This variable is intended to control for secular growth in wages.

${ }^{13}$ Baby and birth characteristics are set to zero in regressions for the no-baby controls.

${ }^{14}$ Complete regression results are not presented here to save space, but are available upon request.
} 
The figure also shows the relationship between maternity leave and wages around the randomly chosen birthdays of control sample women ${ }^{15}$. Here too, we find large positive "effects" of maternity leave coverage, ranging between 10 and 25 percent. The estimates for the main and control samples are remarkably similar in both magnitude and trend, although the estimates for the control sample are less precise. ${ }^{16}$ Because it is difficult to envision how maternity leave coverage per se would cause women who did not give birth to have higher wages in the years after a randomly chosen birthday, we infer from these findings that much of the apparent positive "effects" of maternity leave coverage for the control group is attributable to unobserved heterogeneity, and not to a causal effect of maternity leave coverage.

Figure 2 controls for pre-birth wage, i.e., women's wages at their last working interview before childbirth (or before the selected birthday for the control group). The pre-birth wage is meant to capture unobserved attributes of women that correlate with maternity leave coverage. The estimates are markedly smaller than the previous estimates for women who had babies as well as for women in the control sample. Moreover, for women who had babies the positive effects are concentrated in the years shortly after childbirth. The benefits are between 5 and 10 percent in the first three years. In the fourth year, the benefits drop off considerably and (with the exception of the $5^{\text {th }}$ year) remain small and

\footnotetext{
${ }^{15}$ These are women who did not have a birth in the period covered by the data. At the end of the sample period, they were between 31 and 39 years old.

${ }^{16}$ Most women had babies so the control sample is substantially smaller than the sample of women with babies.
} 
insignificant thereafter. In the control sample, the "effects" of maternity leave are consistently small and insignificant. The above findings suggest that taking into account pre-birth wages goes a long way towards controlling for heterogeneity. ${ }^{17}$

Maternity leave coverage may help preserve employment relationships, i.e., specific human capital or good job matches, and labor market attachment. For preservation of employment relationships, we use job tenure post-birth. High tenure jobs are likely to have high levels of specific human capital. For preservation of labor market attachment, we use the proportion of weeks since birth that the woman worked. Labor market attachment is related to women's incentive to invest in human capital. We obtained estimates by controlling for these variables with the goal of evaluating their importance in determining wages and assessing the extent to which maternity leave may be linked to them.

The estimates in tables $2 \mathrm{a}$ and $2 \mathrm{~b}$ indicate that even after controlling for the pre-birth wage, job tenure post-birth and the proportion of weeks worked since the birth are important determinants of wages in all years. Typically, a log point increase in tenure is associated with 3 to 5 percent higher wages, although the estimates in the control sample tend to be at the lower end of this range. Moreover, controlling for pre-birth wages, post-birth job tenure, and the fraction of time worked after childbirth (or the equivalent birthday) essentially eliminates the maternity leave effects. Figure 3 plots these effects. This finding suggests that much of the estimated maternity leave effect operates through the preservation

\footnotetext{
${ }^{17}$ We also have experimented with models that interact coverage with the mother's age at child birth, her education, and her AFQT score, but none of these interactions were statistically significant in the wage regressions or the other regressions.
} 
of employment relationships and labor market attachment.

\section{Preservation of Employment Relationships and Labor Market Attachment}

The fact that including variables for the preservation of employment relationships and labor market attachment reduces maternity leave effects so much suggests that maternity leave coverage affects wages mainly through these variables. We now investigate how maternity leave coverage affects these variables. A finding that maternity leave coverage has a long lasting effect on these variables would cast doubt on our finding of short-lived maternity leave effects on wages. In contrast, a finding that the effects on these variables are short-lived will increase our confidence in our findings on the wage effects.

\section{Job Tenure Post-Birth}

Figure 4 shows the relationship between maternity leave coverage and job tenure post-birth. As in equation (1), the specification is a linear model, where the dependent variable is $\ln \left(T E N U R E_{\text {ict }}\right)$, the number of weeks respondent $i$ has worked on her primary job at the time of the interview in year $t$ after confinement $c$. Job tenure is an attractive measure of employment preservation in that it is more sensitive to separations from higher tenure jobs. Many women may switch jobs shortly after childbirth, but a large number of them may be women with lowtenure jobs. Alternatively, relatively few women may lose their jobs, but those who do may have trouble finding durable new jobs. Focusing on job tenure provides a parsimonious measure of the durability of women's employment 
relationships.

The findings indicate that in the year after childbirth, women with maternity leave coverage have tenure that is 40 percent higher than those without. This differential remains positive and statistically significant, except for the second year, for the first four years after childbirth before declining and becoming insignificant in the fifth through eighth years. These estimates indicate that maternity leave coverage is associated with the preservation of employment relationships immediately following childbirth. Again, the effects are relatively short-lived. The declining differential indicates that, as time passes, women with maternity leave coverage "catch up" on job turnover relative to those without coverage or that women without maternity leave coverage "catch up" by obtaining new, long-term employment relationships.

Figure 4 also shows estimates for the control sample. Here, women with maternity leave coverage have slightly higher job tenure after their birthdays than those without coverage, but the estimates are insignificant, except in the eighth year.

Figure 5 eliminates the pre-birth wage as an independent variable. Not controlling for the pre-birth wage leads to large, positive effects of maternity leave on tenure among women who had babies. It also implies large, positive "effects" of maternity leave coverage for women in the control sample. It is unlikely that maternity leave coverage is responsible for higher tenure among control sample women, since the coverage should have no effect on them. Thus, these results point to the importance of unobserved worker heterogeneity that is related to 
whether or not women are covered by maternity leave policies.

\section{Labor Market Attachment}

We turn now to how labor market attachment is affected by maternity leave coverage. Labor market attachment differs from job tenure in that it does not depend on the continuity of particular employment relationships, but it is related to the incentive to invest in human capital. The specification underlying Figure 6 is similar to equation (1), with the dependent variable being the proportion of weeks since birth that the woman worked. The estimates indicate that maternity leave coverage increases the fraction of weeks worked by $0.09 \mathrm{a}$ year after childbirth. Thereafter, the differential declines monotonically becoming statistically insignificant after the sixth year.

In Figure 6, the estimate for each year represents the effects of maternity leave coverage on the cumulative fraction of weeks worked since the birth, where the fraction in a particular year depends on the weeks worked in earlier years. It is informative to ascertain the non-cumulative contemporaneous effect of maternity leave coverage for each year by netting out the accumulated effects from previous years. To this end, Figure 6 depicts a "no-contemporaneous effect" series with circles. This series is obtained as follows. Let $\beta_{t}$ denote the cumulative effect for year $t$ and $\beta_{t}^{*}$ the non-cumulative contemporaneous effect. These effects are linked to each other as follows.

$$
\beta_{t}=\beta_{t-1} \frac{t-1}{t}+\beta_{t}^{*} \frac{1}{t}
$$


The no-contemporaneous effect series $\left(\beta_{t}^{0}\right)$ indicated with circles is obtained by setting $\beta_{t}^{*}=0$, or as

$$
\beta_{t}^{0}=\beta_{t-1} \frac{t-1}{t}
$$

This series gives the difference in the fraction of weeks worked between women with maternity leave coverage and those with out it that would be expected in year $t$ given the difference through year $t-1$ and assuming that there is no difference in year $t$. The difference between the observed (cumulative) effect and the no-contemporaneous effect is given by

$$
\beta_{t}-\beta_{t}^{0}=\beta_{t}^{*} \frac{1}{t} .
$$

The quantity $\left(\beta_{t}-\beta_{t}^{0}\right)$ is indicated in Figure 6 by the vertical distance between the triangular tick and the circle. When this quantity is positive, it indicates a positive non-cumulative contemporaneous effect, and when it is small or zero, it indicates no such effect. The non-cumulative contemporaneous effects are positive for the first three years, but they are quite small for the second and third years, indicating that the effect on weeks worked is concentrated in the first year after child birth.

Evidently, women with maternity leave coverage work more during the first year after childbirth than women without coverage, but any difference in labor market attachment quickly disappears. There is no difference in weeks worked between women with maternity leave coverage and those without it in the absence of childbirth. 
What inference may be drawn from greater work in the first year after childbirth is unclear. On the one hand, greater employment may indicate that many women want to return to their jobs soon after childbirth, but that those whose pre-birth jobs had maternity leave coverage are relatively more able to do so. Alternatively, women may return to their jobs more quickly if they had maternity leave coverage than if they didn't because the policies cover only a short period of absence (typically 12 weeks, including FMLA, in the United States). Indeed, Berger and Waldfogel (2003) find that women with leave coverage are more likely to take a leave of six to twelve weeks (the maximum in typical provisions in the U.S.) after childbirth, but are less likely than women without coverage to take a leave longer than twelve weeks.

\section{Summary}

Maternity leave coverage is expected to matter most when durable employment relationships are important. Maternity leave coverage should affect the preservation of employment relationships, that is, specific human capital and good job matches, and the preservation of labor market attachment, as well as wages. Accordingly, we investigate the effects of maternity leave coverage on a variety of outcomes - wages, job tenure post-birth, and labor market attachment.

Our estimates for the three dependent variables are consistent with one another: wage benefits last for approximately the length of time for which there are differences in job tenure and labor market attachment between women with maternity leave coverage and those without it. When pre-birth wages are 
controlled for, the effects decrease markedly, showing benefits only in the few years immediately after the birth and little or no long-term benefits.

Evidently, there is strong selection into jobs with maternity leave coverage on the basis of unobserved factors. Despite our best effort, our correction may be incomplete. If so, our estimated maternity-leave effects, small as they are, may still overstate the true magnitudes. Our findings of selection into jobs with maternity leave coverage suggest that individual-level estimates of benefits on children may be overstated by selection as well. This issue needs further study.

Our findings of small and short-lived maternity leave effects perhaps are understandable given that FLMA and most other leave policies in the United States allow leaves for 12 weeks at most, with the later weeks typically uncompensated. It does not seem plausible that a leave of such a short duration could have large and long-lasting effects on wages and employment. 


\section{References}

Barrow, Lisa. 1999. "An Analysis of Women's Return-To-Work Decisions Following First Birth," Economic Inquiry, 37, No. 3 (July): 432-451.

Berger, Lawrence and Jane Waldfogel. 2003. "Maternity Leave and the Employment of New Mothers in the United States," Journal of Population Economics, forthcoming.

Blau Francine D. and Lawrence Kahn. 2000. "Gender Differences in Pay," Journal of Economic Perspectives, 14 (Fall), 75-99.

Han, Wen-Jui and Jane Waldfogel. 2003. "Parental Leave: The Impact of Recent Legislation on Parent's Leave Taking," Demography, 40, No. 1 (Feb.): 191-200.

Hashimoto, Masanori. 1981. "Firm-Specific Human Capital as Shared Investment," American Economic Review, 71, (June) 475-482.

Jacobson, Joyce and Laurance Levin. 1995. "The Effects of Intermittent Labor Force Attachment on Women's Earnings," Monthly Labor Review, 118, (September): 14-19.

Klerman, Jacob Alex and Arleen Leibowitz. 1997. "Labor Supply Effects of State Maternity Leave Legislation," In Gender and Family Issues in Workplace, Francine D. Blau and Ronald G. Ehrenberg (eds), New York: Russel Sage Foundation: 65-91.

Lazear, Edward P. 1990. "Job Security Provisions and Employment," Quarterly Journal of Economics (August): 699-726.

Olsen, Craig. 2000. "Part-Time Work, Health Insurance, Coverage, and the Wages of Married Women," In Employee Benefits and Labor Markets in Canada and the United States. Kalamazoo, William T. Alpert and Stephen Woodbury (eds), W.E. Upjon Institute for Employment Research, 2000: 295-324.

Mincer, Jacob, and Solomon W. Polacheck 1974. "Family Investment in Human Capital: Earnings of Women," Journal of Political Economy, (March 1974 Supplement): S76S108.

Ruhm, Christopher J. 1998. "The Economic Consequences of Parental Leave Mandates: Lessons from Europe," Quarterly Journal of Economics, 113 (1) (February): 284 - 317.

19 (6) (November): 931-60.

. 2000. "Parental Leave and Child Health," Journal of Health Economics,

Ruhm, Christopher J. and Jackqueline L. Teague. 1998. "Parental Leave Policies in Europe and North America." In Women in the Labor Market, Volume 2, Marianne A. Farber (ed), Cheltenham, UK: Elgar: 473-98.

Waldfogel, Jane. 1997. "Working Mothers Then and Now: A Cross-Cohort Analysis of the Effects of Maternity Leave on Women's Pay," In Gender and Family Issues in the 
Workplace, Francine D. Blau and Ronald G. Ehrenberg (eds), New York: Russel Sage Foundation: 65-91.

1998a. "Understanding the 'Family Gap' in Pay for Women with Children," Journal of Economic Perspectives, 12 (winter): 137-56.

. 1998b. "The Family Gap for Young Women in the United States and Britain: Can Maternity Leave Make a Difference?" Journal of Labor Economics, vol 16, Number 3 (July): pp. 505-545.

Waldfogel, Jane, Yoshio Higuchi, and Masahiro Abe. (1999), "Family Leave Policies and Women's Retention after Childbirth: Evidence from the United States, Britain, and Japan," Population Economics, Vol.12, No.4. 


\begin{tabular}{|c|c|c|c|c|c|c|}
\hline \multicolumn{7}{|c|}{ Table 1a. Sample Selection - Main Sample (Women with Confinements) } \\
\hline & & & \multicolumn{4}{|c|}{ Mean (Standard Deviation) of Selected Variables } \\
\hline Reason for Deletion & $\begin{array}{l}\text { Number } \\
\text { Deleted }\end{array}$ & $\begin{array}{c}\text { Number } \\
\text { Remaining }\end{array}$ & $\begin{array}{l}\text { Mother's } \\
\text { Age }\end{array}$ & Education & AFQT & $\begin{array}{c}\text { Proportion } \\
\text { of Weeks } \\
\text { Worked } \\
\text { After Birth } \\
\end{array}$ \\
\hline $\begin{array}{l}\text { 1. Number of } \\
\text { Confinements }\end{array}$ & & 10,378 & $\begin{array}{l}24.655 \\
(4.968)\end{array}$ & $\begin{array}{l}12.188 \\
(2.331)\end{array}$ & $\begin{array}{c}34.831 \\
(26.912)\end{array}$ & $.249(.364)$ \\
\hline $\begin{array}{l}\text { 2. Siblings born } \\
\text { within } 365 \text { days }\end{array}$ & -293 & 10,085 & $\begin{array}{l}24.730 \\
(4.972)\end{array}$ & $\begin{array}{l}12.222 \\
(2.320)\end{array}$ & $\begin{array}{c}35.252 \\
(26.960)\end{array}$ & $.252(.365)$ \\
\hline $\begin{array}{l}\text { 3. Children born } \\
\text { before first interview }\end{array}$ & $-1,242$ & 8,843 & $\begin{array}{l}25.650 \\
(4.570)\end{array}$ & $\begin{array}{l}12.222 \\
(2.320)\end{array}$ & $\begin{array}{c}36.434 \\
(27.227)\end{array}$ & $.252(.365)$ \\
\hline $\begin{array}{l}\text { 4. Not working } \\
\text { before birth, no } \\
\text { reported wage or } \\
\text { wage outliers }\end{array}$ & $-3,864$ & 4,979 & $\begin{array}{l}26.143 \\
(4.296)\end{array}$ & $\begin{array}{l}12.692 \\
(2.169)\end{array}$ & $\begin{array}{l}40.710 \\
(27.058)\end{array}$ & $.360(.395)$ \\
\hline $\begin{array}{l}\text { 5. Missing maternity } \\
\text { leave coverage }\end{array}$ & $-2,077$ & 2,902 & $\begin{array}{l}28.320 \\
(3.394)\end{array}$ & $\begin{array}{l}13.182 \\
(2.195)\end{array}$ & $\begin{array}{c}42.944 \\
(27.408)\end{array}$ & $.423(.407)$ \\
\hline $\begin{array}{l}\text { 6. Missing single- } \\
\text { point covariate } \\
\text { (AFQT, Mother's } \\
\text { Age) }\end{array}$ & -75 & 2,827 & $\begin{array}{l}28.323 \\
(3.401)\end{array}$ & $\begin{array}{l}13.192 \\
(2.200)\end{array}$ & $\begin{array}{c}42.944 \\
(27.408)\end{array}$ & $.425(.408)$ \\
\hline $\begin{array}{l}\text { 7. Missing basic, } \\
\text { varying covariate } \\
\text { (Time Since Birth, } \\
\text { Marital Status, } \\
\text { Education) }\end{array}$ & -456 & 2,371 & $\begin{array}{l}28.204 \\
(3.297)\end{array}$ & $\begin{array}{l}13.151 \\
(2.185)\end{array}$ & $\begin{array}{c}42.988 \\
(27.366)\end{array}$ & $.473(.403)$ \\
\hline $\begin{array}{l}\text { 8. Missing tenure } \\
\text { before birth }\end{array}$ & -2 & 2,369 & $\begin{array}{l}28.199 \\
(3.294)\end{array}$ & $\begin{array}{l}13.150 \\
(2.184)\end{array}$ & $\begin{array}{c}42.984 \\
(27.360)\end{array}$ & $.472(.403)$ \\
\hline \multicolumn{7}{|c|}{ Additional Deletions Based on Dependent Variables (relative to line 8) } \\
\hline $\begin{array}{l}\text { Missing tenure in } \\
\text { first year after birth }\end{array}$ & -296 & 2,073 & $\begin{array}{l}28.270 \\
(3.291)\end{array}$ & $\begin{array}{l}13.256 \\
(2.158)\end{array}$ & $\begin{array}{c}44.239 \\
(27.207)\end{array}$ & $.535(.388)$ \\
\hline $\begin{array}{l}\text { Missing fraction of } \\
\text { weeks since birth } \\
\text { worked (WKRATIO) } \\
\text { in year } 1\end{array}$ & -149 & 2,220 & $\begin{array}{l}28.225 \\
(3.305)\end{array}$ & $\begin{array}{l}13.199 \\
(2.153)\end{array}$ & $\begin{array}{c}43.746 \\
(27.175)\end{array}$ & $.500(.397)$ \\
\hline $\begin{array}{l}\text { Missing above } \\
\text { variables or wage in } \\
\text { first year after birth }\end{array}$ & -318 & 2,051 & $\begin{array}{l}28.279 \\
(3.286)\end{array}$ & $\begin{array}{l}13.255 \\
(2.161)\end{array}$ & $\begin{array}{c}44.248 \\
(27.240)\end{array}$ & $.535(.388)$ \\
\hline
\end{tabular}




\begin{tabular}{|c|c|c|c|c|c|c|}
\hline \multicolumn{7}{|c|}{ Table 1b. Sample Selection - Control Sample } \\
\hline & & & \multicolumn{4}{|c|}{ Mean (Standard Deviation) of Selected Variables } \\
\hline Reason for Deletion & $\begin{array}{l}\text { Number } \\
\text { Deleted }\end{array}$ & $\begin{array}{c}\text { Number } \\
\text { Remaining }\end{array}$ & $\begin{array}{l}\text { Mother's } \\
\text { Age }\end{array}$ & Education & AFQT & $\begin{array}{l}\text { Proportion } \\
\text { of Weeks } \\
\text { Worked } \\
\text { After } \\
\text { Birthday }\end{array}$ \\
\hline $\begin{array}{l}\text { 1. Number of } \\
\text { Confinements }\end{array}$ & & 1,573 & $\begin{array}{l}24.512 \\
(2.896)\end{array}$ & $\begin{array}{l}13.230 \\
(2.011)\end{array}$ & $\begin{array}{c}49.325 \\
(27.555)\end{array}$ & $.662(.383)$ \\
\hline $\begin{array}{l}\text { 2. Siblings born within } \\
365 \text { days }\end{array}$ & - & 1,573 & $\begin{array}{l}24.512 \\
(2.896)\end{array}$ & $\begin{array}{l}13.230 \\
(2.011)\end{array}$ & $\begin{array}{l}49.325 \\
(27.555)\end{array}$ & $.662(.383)$ \\
\hline $\begin{array}{l}\text { 3. Children born before } \\
\text { first interview }\end{array}$ & -77 & 1,496 & $\begin{array}{l}24.722 \\
(2.811)\end{array}$ & $\begin{array}{l}13.230 \\
(2.011)\end{array}$ & $\begin{array}{l}50.260 \\
(27.045)\end{array}$ & $.662(.383)$ \\
\hline $\begin{array}{l}\text { 4. Not working before } \\
\text { birthday, no reported } \\
\text { wage or wage outliers }\end{array}$ & -525 & 970 & $\begin{array}{l}24.567 \\
(2.766)\end{array}$ & $\begin{array}{l}13.440 \\
(1.960)\end{array}$ & $\begin{array}{l}50.260 \\
(27.045)\end{array}$ & $.761(.319)$ \\
\hline $\begin{array}{l}\text { 5. Missing maternity } \\
\text { leave coverage }\end{array}$ & -515 & 455 & $\begin{array}{l}26.380 \\
(2.033)\end{array}$ & $\begin{array}{l}13.577 \\
(2.094)\end{array}$ & $\begin{array}{c}48.047 \\
(27.881)\end{array}$ & $.805(.298)$ \\
\hline $\begin{array}{l}\text { 6. Missing single-point } \\
\text { covariate (AFQT, } \\
\text { Mother's Age) }\end{array}$ & -5 & 450 & $\begin{array}{l}26.369 \\
(2.037)\end{array}$ & $\begin{array}{l}13.696 \\
(2.099)\end{array}$ & $\begin{array}{c}48.047 \\
(27.881)\end{array}$ & $.808(.297)$ \\
\hline $\begin{array}{l}\text { 7. Missing basic, } \\
\text { varying covariate (Time } \\
\text { Since Birth, Marital } \\
\text { Status, Education) }\end{array}$ & -85 & 365 & $\begin{array}{l}26.419 \\
(1.988)\end{array}$ & $\begin{array}{l}13.718 \\
(2.073)\end{array}$ & $\begin{array}{c}47.795 \\
(27.939)\end{array}$ & $.808(.297)$ \\
\hline $\begin{array}{l}\text { 8. Missing tenure } \\
\text { before birth }\end{array}$ & -0 & 365 & $\begin{array}{l}26.419 \\
(1.988)\end{array}$ & $\begin{array}{l}13.718 \\
(2.073)\end{array}$ & $\begin{array}{c}47.795 \\
(27.939)\end{array}$ & $.808(.297)$ \\
\hline Additio & eletic & sed on & endent Va & bles (relati) & to line 8) & \\
\hline $\begin{array}{l}\text { Missing tenure in } \\
\text { first year after birth }\end{array}$ & -16 & 349 & $\begin{array}{l}26.413 \\
(1.974)\end{array}$ & $\begin{array}{l}13.782 \\
(2.067)\end{array}$ & $\begin{array}{c}47.871 \\
(28.009)\end{array}$ & $.821(.280)$ \\
\hline $\begin{array}{l}\text { Missing fraction of } \\
\text { weeks since birth } \\
\text { worked (WKRATIO) } \\
\text { in year } 1\end{array}$ & -16 & 349 & $\begin{array}{l}26.413 \\
(1.974)\end{array}$ & $\begin{array}{l}13.782 \\
(2.067)\end{array}$ & $\begin{array}{c}47.871 \\
(28.009)\end{array}$ & $.821(.280)$ \\
\hline $\begin{array}{l}\text { Missing above } \\
\text { variables or wage in } \\
\text { first year after birth }\end{array}$ & -17 & 348 & $\begin{array}{l}26.414 \\
(1.977)\end{array}$ & $\begin{array}{l}13.776 \\
(2.067)\end{array}$ & $\begin{array}{c}47.767 \\
(27.982)\end{array}$ & $.820(.281)$ \\
\hline
\end{tabular}




\begin{tabular}{|c|c|c|c|c|c|c|c|c|c|c|c|c|c|c|c|c|}
\hline \multirow[b]{2}{*}{$\begin{array}{l}\text { Maternity Leave } \\
\text { Coverage }\end{array}$} & \multicolumn{2}{|c|}{ Year 1} & \multicolumn{2}{|c|}{ Year 2} & \multicolumn{2}{|c|}{ Year 3} & \multicolumn{2}{|c|}{ Year 4} & \multicolumn{2}{|c|}{ Year 5} & \multicolumn{2}{|c|}{ Year 6} & \multicolumn{2}{|c|}{ Year 7} & \multicolumn{2}{|c|}{ Year 8} \\
\hline & .042 & $(.023)$ & .063 & (.028) & .045 & $(.028)$ & -.011 & $(.030)$ & .061 & $(.033)$ & .006 & $(.037)$ & .038 & $(.037)$ & .022 & $(.038)$ \\
\hline $\begin{array}{l}\text { Proportion of } \\
\text { Weeks Worked } \\
\text { After Birth }\end{array}$ & .079 & $(.025)$ & .172 & $(.044)$ & .329 & $(.052)$ & .230 & $(.055)$ & .315 & $(.063)$ & .446 & $(.068)$ & .278 & $(.071)$ & .260 & $(.073)$ \\
\hline Log Tenure & .040 & $(.006)$ & .046 & $(.007)$ & .028 & $(.007)$ & .031 & $(.007)$ & .041 & $(.008)$ & .023 & $(.009)$ & .051 & $(.009)$ & .056 & $(.009)$ \\
\hline $\begin{array}{l}\text { Log of Pre-Birth } \\
\text { Wage }\end{array}$ & .590 & $(.020)$ & .457 & $(.023)$ & .495 & $(.024)$ & .425 & $(.026)$ & .451 & $(.031)$ & .403 & $(.034)$ & .353 & $(.035)$ & .363 & $(.039)$ \\
\hline $\begin{array}{l}\text { Log Pre-Birth } \\
\text { Tenure }\end{array}$ & -.012 & $(.009)$ & -.018 & $(.010)$ & -.012 & $(.010)$ & -.002 & $(.011)$ & -.025 & $(.012)$ & -.001 & $(.013)$ & -.017 & $(.014)$ & -.024 & $(.014)$ \\
\hline $\begin{array}{l}\text { Log Pre-Birth } \\
\text { Tenure }^{2}\end{array}$ & .006 & $(.004)$ & .001 & $(.004)$ & -.002 & $(.004)$ & .000 & $(.005)$ & -.001 & $(.005)$ & .001 & $(.006)$ & .002 & $(.006)$ & .004 & $(.007)$ \\
\hline Time Elapsed & -.001 & $(.053)$ & -.030 & $(.032)$ & -.028 & $(.030)$ & .005 & $(.031)$ & .009 & $(.035)$ & .006 & $(.038)$ & .018 & $(.037)$ & .032 & $(.035)$ \\
\hline Mother is Married & .031 & $(.023)$ & .000 & $(.027)$ & -.032 & $(.028)$ & -.018 & $(.029)$ & -.055 & $(.033)$ & -.042 & $(.037)$ & -.007 & $(.037)$ & -.042 & $(.038)$ \\
\hline $\begin{array}{l}\text { Highest Grade } \\
\text { Completed }\end{array}$ & .014 & $(.006)$ & .030 & $(.007)$ & .033 & $(.007)$ & .039 & $(.008)$ & .046 & $(.009)$ & .034 & $(.010)$ & .050 & $(.010)$ & .031 & $(.011)$ \\
\hline Mother is Black & .039 & $(.026)$ & .040 & $(.030)$ & -.016 & $(.031)$ & .028 & $(.033)$ & -.029 & $(.038)$ & .057 & $(.042)$ & -.028 & $(.042)$ & .085 & $(.044)$ \\
\hline Mother is Hispanic & .065 & $(.025)$ & .107 & $(.030)$ & .046 & $(.030)$ & .075 & $(.033)$ & .124 & $(.037)$ & .064 & $(.041)$ & .101 & $(.042)$ & .197 & $(.043)$ \\
\hline AFQT & .002 & $(.000)$ & .003 & $(.001)$ & .002 & $(.001)$ & .002 & $(.001)$ & .001 & $(.001)$ & .002 & $(.001)$ & .003 & $(.001)$ & .004 & $(.001)$ \\
\hline Mother's Age & .011 & $(.041)$ & -.026 & $(.050)$ & -.021 & $(.053)$ & .023 & $(.060)$ & -.067 & $(.075)$ & -.012 & $(.084)$ & .010 & $(.093)$ & -.004 & $(.106)$ \\
\hline Mother's Age ${ }^{2}$ & .000 & $(.001)$ & .001 & $(.001)$ & .000 & $(.001)$ & .000 & $(.001)$ & .001 & $(.001)$ & .000 & $(.002)$ & .000 & $(.002)$ & .000 & $(.002)$ \\
\hline Number of Child & -.079 & $(.030)$ & -.013 & $(.036)$ & -.012 & $(.038)$ & -.030 & $(.045)$ & .094 & $(.053)$ & .081 & $(.070)$ & -.006 & $(.059)$ & -.008 & $(.078)$ \\
\hline Number of Child ${ }^{2}$ & .007 & $(.006)$ & -.009 & $(.007)$ & -.003 & $(.007)$ & -.002 & $(.009)$ & -.020 & $(.011)$ & -.017 & $(.015)$ & -.002 & $(.012)$ & -.005 & $(.017)$ \\
\hline $\mathrm{R}^{2}$ & .5 & & .4 & & .4 & & .4 & & .3 & & & & & & & 04 \\
\hline $\begin{array}{l}\text { Number of } \\
\text { Observations }\end{array}$ & 20 & & 18 & & 17 & & 15 & & 13 & & & & & & & 55 \\
\hline
\end{tabular}

Note. Standard errors in parentheses. Estimates include year effects. Time elapsed is time elapsed between pre-birth wage and post-birth wage observations. 


\begin{tabular}{|c|c|c|c|c|c|c|c|c|}
\hline & Year 1 & Year 2 & Year 3 & Year 4 & Year 5 & Year 6 & Year 7 & Year 8 \\
\hline $\begin{array}{l}\text { Maternity Leave } \\
\text { Coverage }\end{array}$ & .005 (.039) & $.054(.059)$ & $-.018(.054)$ & $-.055(.058)$ & $.052(.064)$ & $.019(.074)$ & $.013(.077)$ & $.036(.089)$ \\
\hline $\begin{array}{l}\text { Proportion of Weeks } \\
\text { Worked After Birth }\end{array}$ & $.020(.064)$ & $.155(.118)$ & $.236(.130)$ & $.502(.164)$ & $.254(.170)$ & $.665(.237)$ & $.371(.230)$ & $.438(.264)$ \\
\hline Log Tenure & $.024(.010)$ & $.027(.013)$ & $.030(.013)$ & $.020(.013)$ & $.017(.017)$ & $-.004(.018)$ & $.033(.017)$ & $-.020(.020)$ \\
\hline $\begin{array}{l}\text { Log of Pre-Birthday } \\
\text { Wage }\end{array}$ & $.668(.044)$ & $.578(.061)$ & $.532(.057)$ & $.546(.061)$ & $.390(.067)$ & $.426(.084)$ & $.438(.080)$ & $.386(.098)$ \\
\hline $\begin{array}{l}\text { Log Pre-Birthday } \\
\text { Tenure }\end{array}$ & $.007(.016)$ & $-.033(.021)$ & $-.016(.020)$ & $.000(.021)$ & $-.009(.024)$ & $.004(.028)$ & $-.026(.027)$ & $.034(.031)$ \\
\hline $\begin{array}{l}\text { Log Pre-Birthday } \\
\text { Tenure }^{2}\end{array}$ & $.001(.008)$ & $-.013(.011)$ & $.006(.011)$ & $.009(.011)$ & $-.003(.012)$ & $-.007(.014)$ & $-.020(.015)$ & $-.008(.016)$ \\
\hline Time Elapsed & $-.010(.088)$ & $.076(.064)$ & $-.030(.061)$ & $-.023(.063)$ & $-.012(.072)$ & $-.061(.084)$ & $.013(.086)$ & $.003(.086)$ \\
\hline Mother is Married & $-.028(.041)$ & $-.014(.055)$ & $-.049(.054)$ & $.005(.055)$ & $-.010(.063)$ & $-.114(.075)$ & $-.055(.077)$ & $.039(.090)$ \\
\hline $\begin{array}{l}\text { Highest Grade } \\
\text { Completed }\end{array}$ & $.006(.010)$ & $-.001(.013)$ & $.035(.013)$ & $.044(.014)$ & $.063(.016)$ & $.052(.018)$ & $.031(.019)$ & $.050(.024)$ \\
\hline Mother is Black & $-.012(.042)$ & $-.021(.061)$ & $-.031(.056)$ & $-.023(.059)$ & $-.011(.067)$ & $-.037(.079)$ & $.042(.078)$ & $.080(.100)$ \\
\hline Mother is Hispanic & $.012(.047)$ & $.121(.068)$ & $.102(.061)$ & $.120(.064)$ & $-.008(.074)$ & $.016(.083)$ & $.054(.090)$ & $.286(.096)$ \\
\hline AFQT & $.001(.001)$ & $.002(.001)$ & $.001(.001)$ & $.001(.001)$ & $.002(.001)$ & $.002(.001)$ & $.004(.002)$ & $.004(.002)$ \\
\hline Mother's Age & $.128(.211)$ & $-.053(.292)$ & $.348(.281)$ & $.031(.279)$ & $.446(.307)$ & $.149(.365)$ & $.228(.368)$ & $-.537(.407)$ \\
\hline Mother's Age ${ }^{2}$ & $-.003(.004)$ & $.001(.006)$ & $-.007(.005)$ & $-.001(.005)$ & $-.009(.006)$ & $-.003(.007)$ & $-.005(.007)$ & $.010(.008)$ \\
\hline $\mathrm{R}^{2}$ & .594 & .402 & .437 & .406 & .388 & .394 & .377 & .494 \\
\hline $\begin{array}{l}\text { Number of } \\
\text { Observations }\end{array}$ & 348 & 346 & 355 & 329 & 301 & 240 & 214 & 150 \\
\hline
\end{tabular}

Note. Standard errors in parentheses. Estimates include year effects. Time elapsed is time elapsed between pre-birthday wage and post-birthday wage observations. 


\section{Figure 1 - Wage (in Natural Log) and Maternity Leave}

Not Controlling for Pre-Birth Wage

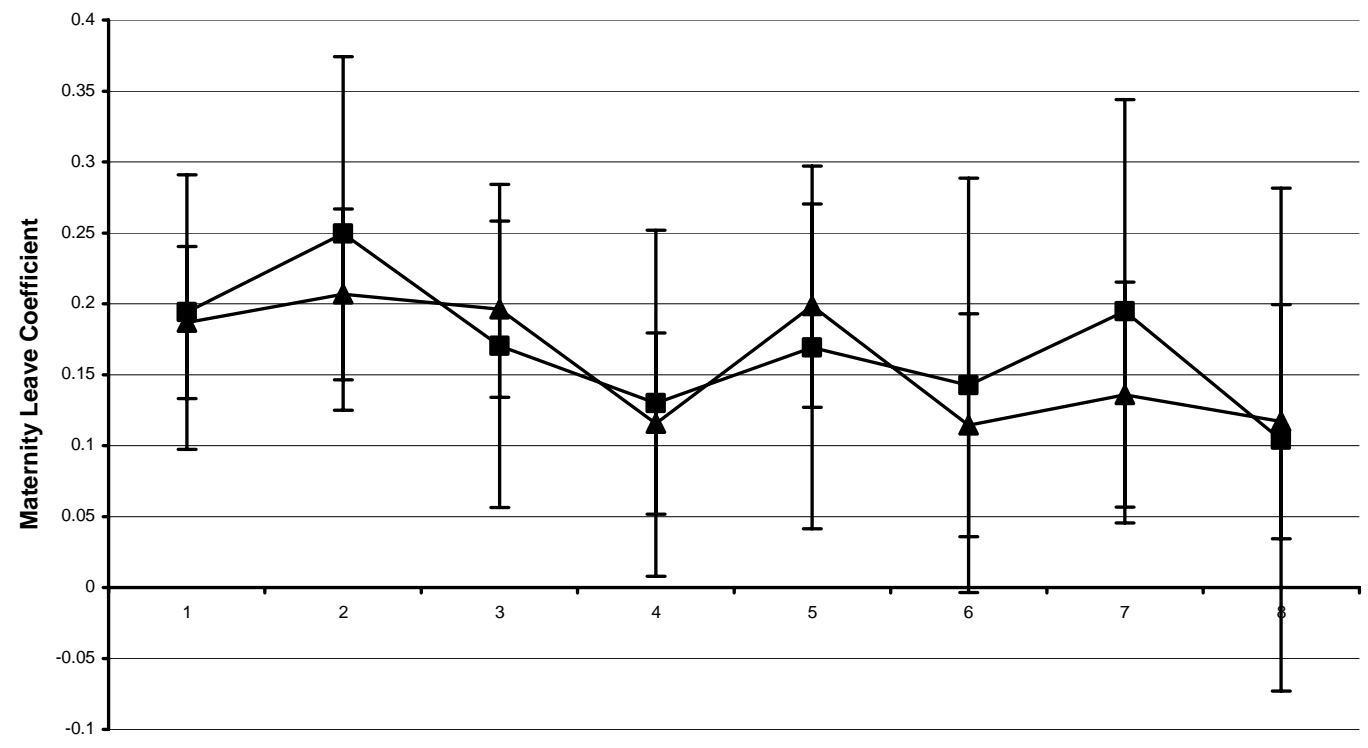

Years Since Child Birth / Birthday

$\longrightarrow$ With Baby $\rightarrow$-No Baby Controls

Note. Figures report point estimates of maternity leave coefficient and the $95 \%$ confidence interval. Separate regressions were run for each year and for each sample. Control variables include the log of tenure before the birth and its square, the number of weeks elapsed since the last pre-birth interview, marital status, education, dummy variables for whether the mother is black and whether she is Hispanic, the mother's score on the Armed Forces Qualifying Test, the mother's age and its square, the birth-order number of the child and its square, and calendar-year dummy variables. 
Figure 2 - Wage (in Natural Log) and Maternity Leave

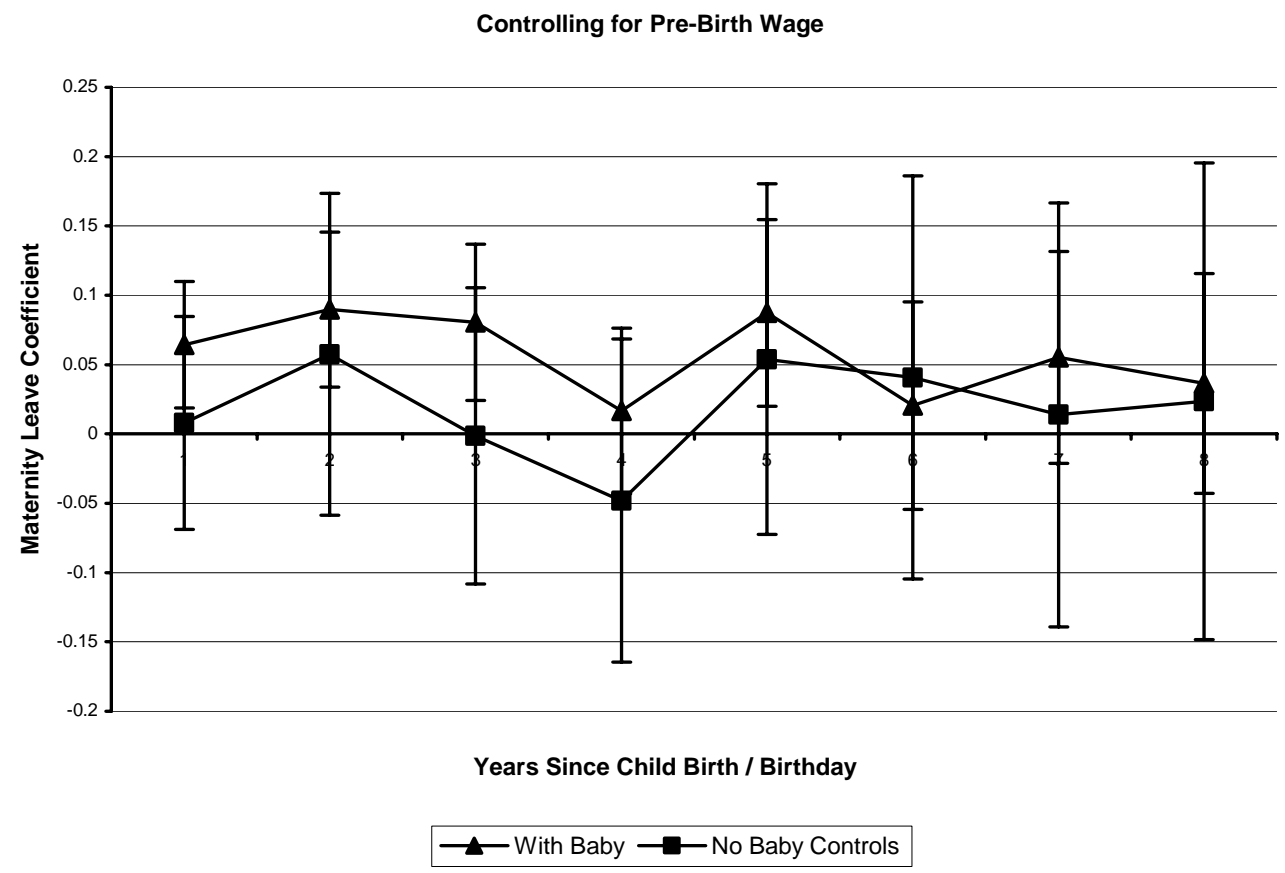

Note. Figures report point estimates of maternity leave coefficient and $95 \%$ confidence interval. Separate regressions were run for each year and sample. Control variables include those listed in Figure 1 and log wage before the birth. 
Figure 3 - Wage (in Natural Log) and Maternity Leave

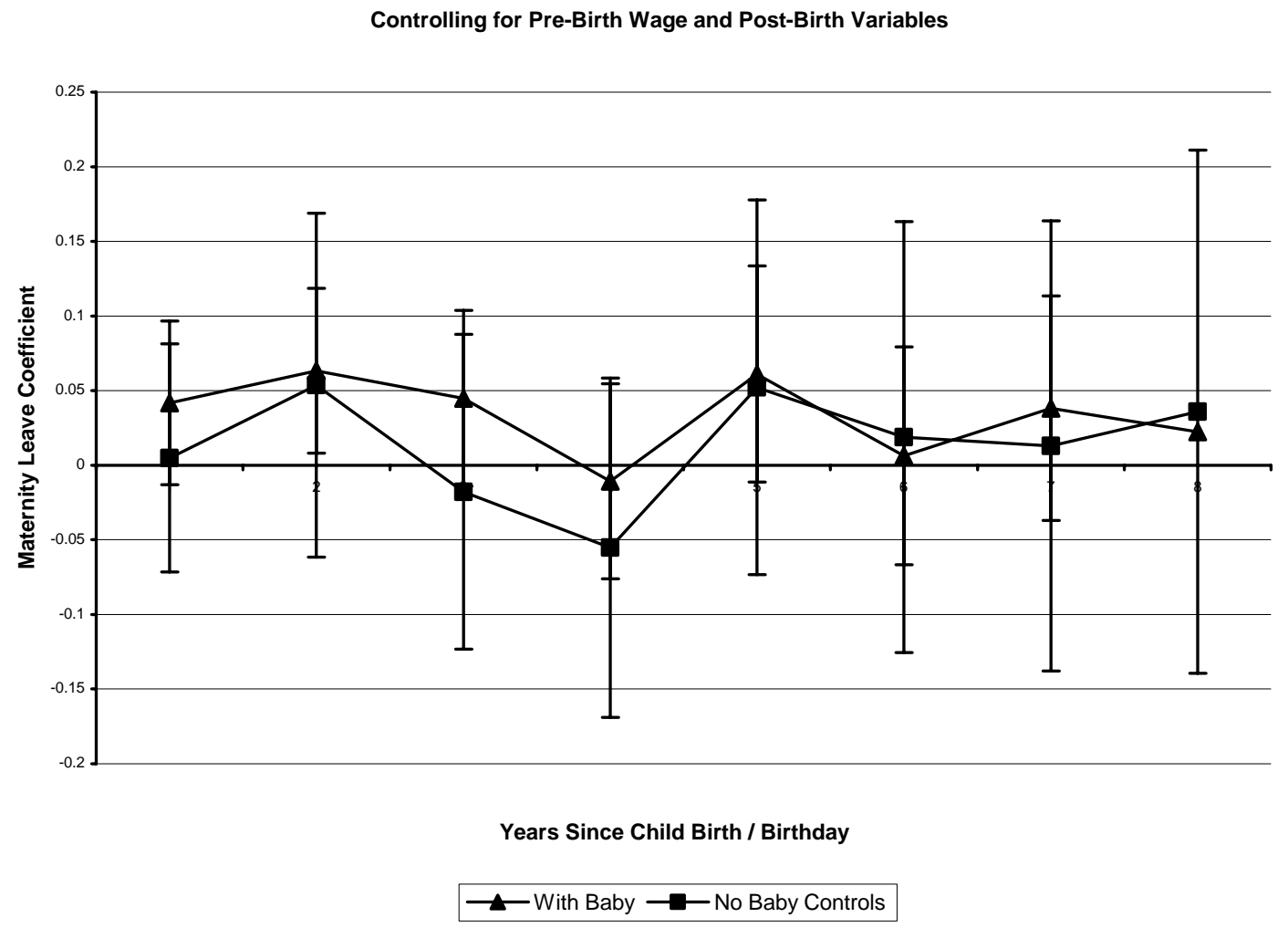

Note. Figures report point estimates of maternity leave coefficient and $95 \%$ confidence interval. Separate regressions were run for each year and sample. Control variables include those listed in Figure 1, log wage before the birth, current log job tenure, and fraction of weeks worked since the birth. 


\section{Figure 4 - Job Tenure Post-Birth (in Natural Log) and Maternity Leave}

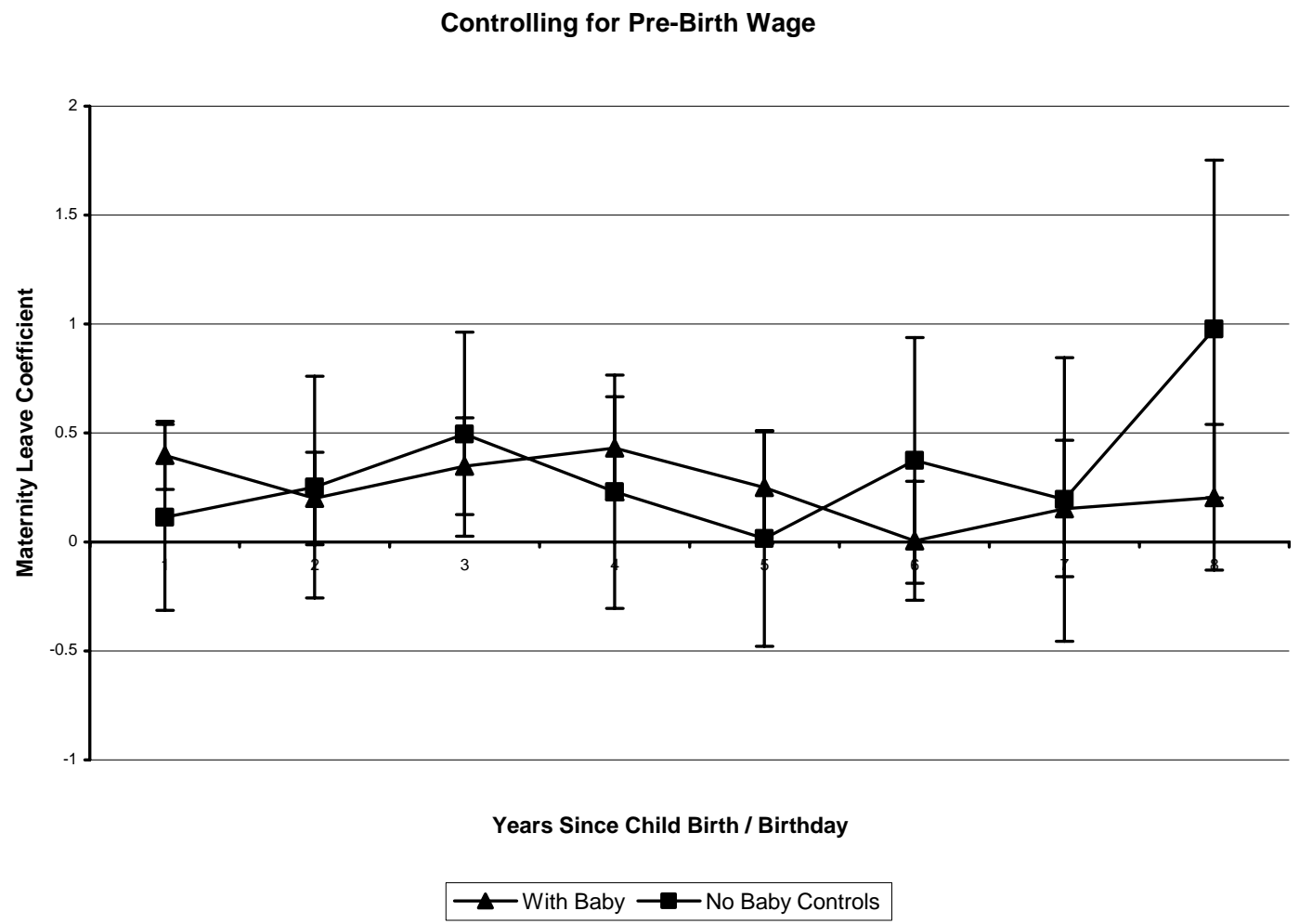

Note. Figures report point estimates of maternity leave coefficient and 95\% confidence interval. Separate regressions were run for each year and sample. Control variables include the log of tenure before the birth and its square, the number of weeks elapsed since the last pre-birth interview, marital status, education, dummy variables for whether the mother is black and whether she is Hispanic, the mother's score on the Armed Forces Qualifying Test, the mother's age and its square, the birth-order number of the child and its square, and calendar-year dummy variables, and log wage before the birth. 


\section{Figure 5 - Job Tenure Post-Birth (in Natural Log) and Maternity Leave}

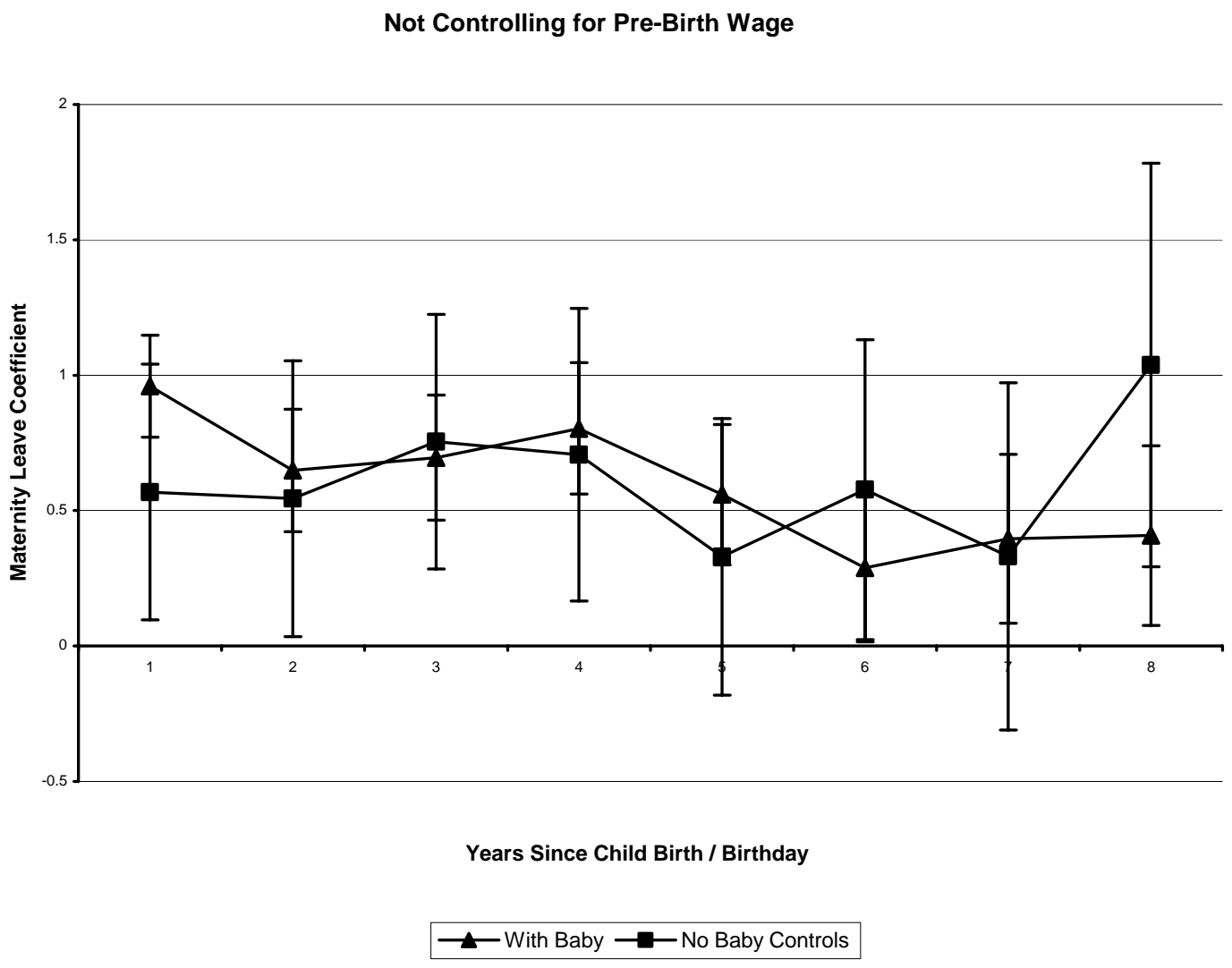

Note. Figures report point estimates of maternity leave coefficient and 95\% confidence interval. Separate regressions were run for each year and sample. Control variables include the log of tenure before the birth and its square, the number of weeks elapsed since the last pre-birth interview, marital status, education, dummy variables for whether the mother is black and whether she is Hispanic, the mother's score on the Armed Forces Qualifying Test, the mother's age and its square, the birth-order number of the child and its square, and calendar-year dummy variables, but not log wage before the birth. 


\section{Figure 6 - Proportion of Weeks Worked Since Confinement}

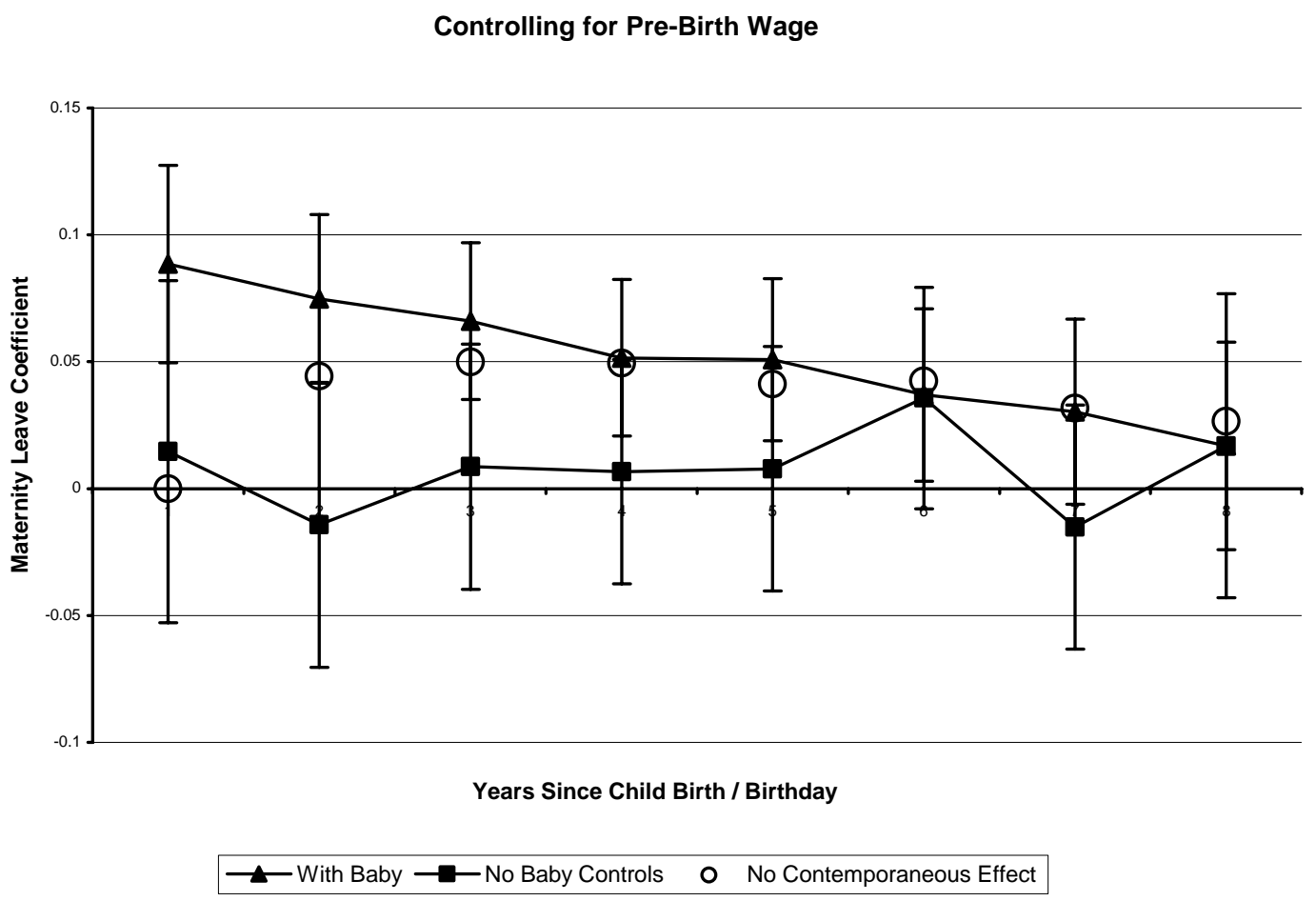

Note. Figures report point estimates of maternity leave coefficient and 95\% confidence interval. Separate regressions were run for each year and sample. Control variables include the log of tenure before the birth and its square, the number of weeks elapsed since the last pre-birth interview, marital status, education, dummy variables for whether the mother is black and whether she is Hispanic, the mother's score on the Armed Forces Qualifying Test, the mother's age and its square, the birth-order number of the child and its square, and calendar-year dummy variables, and log wage before the birth. The no contemporaneous effect series indicates the difference in the proportion of weeks worked by maternity leave coverage that would be observed in year $t$ in the absence of a difference in weeks worked in that year between women with and without coverage, given the differential in year $t-1$. 
Appendix: Coefficient Estimates for Maternity Leave Coverage

\begin{tabular}{|c|c|c|c|c|c|c|c|c|c|c|c|c|}
\hline \multicolumn{13}{|c|}{ Main Sample (Women with Confinement) } \\
\hline & \multicolumn{2}{|c|}{ Wage (Figure 1) } & \multicolumn{2}{|c|}{ Wage (Figure 2) } & \multicolumn{2}{|c|}{ Wage (Figure 3) } & \multicolumn{2}{|c|}{ Job Tenure (Figure 4) } & \multicolumn{2}{|c|}{ Job Tenure (Figure 5) } & \multicolumn{2}{|c|}{ Work Ratio (Figure 6) } \\
\hline Year & MatLeave & SE & MatLeave & SE & MatLeave & SE & MatLeave & SE & MatLeave & SE & MatLeave & SE \\
\hline 1 & 0.187 & 0.027 & 0.064 & 0.023 & 0.042 & 0.023 & 0.397 & 0.080 & 0.960 & 0.096 & 0.088 & 0.020 \\
\hline 2 & 0.207 & 0.031 & 0.090 & 0.029 & 0.063 & 0.028 & 0.200 & 0.108 & 0.648 & 0.115 & 0.075 & 0.017 \\
\hline 3 & 0.196 & 0.032 & 0.081 & 0.029 & 0.045 & 0.028 & 0.348 & 0.113 & 0.696 & 0.118 & 0.066 & 0.016 \\
\hline 4 & 0.116 & 0.033 & 0.017 & 0.030 & -0.011 & 0.030 & 0.430 & 0.121 & 0.803 & 0.124 & 0.052 & 0.016 \\
\hline 5 & 0.199 & 0.037 & 0.087 & 0.034 & 0.061 & 0.033 & 0.250 & 0.131 & 0.559 & 0.132 & 0.051 & 0.016 \\
\hline 6 & 0.114 & 0.040 & 0.020 & 0.038 & 0.006 & 0.037 & 0.005 & 0.139 & 0.289 & 0.139 & 0.037 & 0.017 \\
\hline 7 & 0.136 & 0.041 & 0.055 & 0.039 & 0.038 & 0.037 & 0.153 & 0.159 & 0.397 & 0.159 & 0.030 & 0.019 \\
\hline 8 & 0.117 & 0.042 & 0.036 & 0.040 & 0.022 & 0.038 & 0.205 & 0.170 & 0.408 & 0.169 & 0.017 & 0.021 \\
\hline \multicolumn{13}{|c|}{ Control Sample } \\
\hline 1 & 0.194 & 0.049 & 0.008 & 0.039 & 0.005 & 0.039 & 0.113 & 0.217 & 0.568 & 0.241 & 0.015 & 0.034 \\
\hline 2 & 0.250 & 0.064 & 0.057 & 0.059 & 0.054 & 0.059 & 0.251 & 0.260 & 0.544 & 0.260 & -0.014 & 0.029 \\
\hline 3 & 0.170 & 0.058 & -0.001 & 0.054 & -0.018 & 0.054 & 0.495 & 0.239 & 0.754 & 0.240 & 0.009 & 0.025 \\
\hline 4 & 0.130 & 0.062 & -0.048 & 0.060 & -0.055 & 0.058 & 0.230 & 0.273 & 0.707 & 0.276 & 0.007 & 0.023 \\
\hline 5 & 0.169 & 0.065 & 0.054 & 0.064 & 0.052 & 0.064 & 0.016 & 0.253 & 0.329 & 0.260 & 0.008 & 0.025 \\
\hline 6 & 0.142 & 0.075 & 0.041 & 0.074 & 0.019 & 0.074 & 0.374 & 0.288 & 0.578 & 0.283 & 0.036 & 0.022 \\
\hline 7 & 0.195 & 0.076 & 0.014 & 0.078 & 0.013 & 0.077 & 0.195 & 0.332 & 0.331 & 0.327 & -0.015 & 0.025 \\
\hline 8 & 0.104 & 0.090 & 0.024 & 0.088 & 0.036 & 0.089 & 0.977 & 0.395 & 1.038 & 0.380 & 0.017 & 0.031 \\
\hline
\end{tabular}

